\title{
回復期リハビリテーション病棟における電子カルテの実態調査
}

\author{
菅原 英和 $* 1$ 八幡徹太郎*2 岡 崎 英人*3 \\ 越智光宏*4 原田雄大*5 嘉村雄飛*6
}

\section{Survey of the Electronic Medical Recoding System Used in Kaifukuki Rehabilitation Wards}

\author{
Hidekazu Sugawara, ${ }^{* 1}$ Tetsutaro Yahata, ${ }^{* 2}$ Hideto OKazaki, ${ }^{* 3}$ \\ Mitsuhiro OchI, ${ }^{* 4}$ Katsuhiro HaRAdA, ${ }^{* 5}$ Yuhi Kamura ${ }^{* 6}$
}

\begin{abstract}
A working group, established by the Japanese Board-certified Physiatrist Association to examine the necessary functions for an electronic medical record keeping system for rehabilitation, created a functional evaluation system for electronic medical record keeping in kaifukuki rehabilitation wards. The group conducted a survey to determine how electronic medical records are actually being used in kaifukuki rehabilitation wards. Methods : The group sent questionnaires to 153 hospitals with kaifukuki rehabilitation wards by mail. The questions included the period of usage, how satisfied they were with their system, and a self-evaluation form for their electronic medical record functional evaluation. They asked the respondents to evaluate each item from 1 to 5 points. Results : The group received answers from 82 institutions, with a valid answer rate of $53.6 \%$ in total. The median of the electronic record functional evaluation was 60.5 points. The points given varied from 1 to 5 in all items. Conclusion : It was determined that electronic medical records are equipped with a minimum of functions for rehabilitation, but also that there are great functional differences among institutions. (Jpn J Rehabil Med 2013; $50 ： 319-327$ )

要 旨：日本リハビリテーション医学会専門医会によって設立された「リハ医療に必要な電 子カルテ機能を検討するワーキンググループ」は「電子カルテ機能評価：回復期リハ病棟版」 を作成し，その機能評価を用いて回復期リ八病棟に㧍ける電子カルテの実態調查を行った。方 法：電子カルテを導入している回復期リハ病棟を有する 153 施設を対象として, 郵送法による アンケート形式の調查を行った。調查では電子カルテ機能評価（回リ八病棟版）の自己採点結 果，電子カルテの使用期間・満足度を尋ねた。結果：有効回答率は $53.6 \%$ (82 施設). 電子力 ルテ機能評価の総合点中央值は 60.5 点. 項目別にみると全項目で $1 \sim 5$ 点までのばらつきが 認められた。結語：回復期リ八病棟に導入されている電子カルテは,リ八医療特有のニーズに 十分に対応しきれておらず，施設によって相当の差があることも判明した。
\end{abstract}

2012 年 10 月 15 日受付, 2013 年 4 月 4 日受理

*1 初台リハビリテーション病院/テ 151-0071 東京都渋谷区本町 3-53-3

Hatsudai Rehabilitation Hospital

*2 金沢大学附属病院リハビリテーション部/テ 920-8641 石川県金沢市宝町 13-1

Section of Physical \& Rehabilitation Medicine, Kanazawa University Hospital

*3 藤田保健衛生大学医学部リハビリテーション医学 II 講座/テ 514-1295 三重県津市大鳥町 424-1

Department of Rehabilitation Medicine II, School of Medicine, Fujita Health University

*4 産業医科大学リハビリテーション医学講座/ $707-8555$ 北九州市八幡西区医生ヶ丘 1-1 Department of Rehabilitation Medicine, University of Occupational and Environmental Health

*5 藤元上町病院リハビリテーション科/テ 885-0072 宮崎県都城市上町 10 街区 24 号

Department of Rehabilitation Medicine, Fujimotokamimachi Hospital

*6 広島市総合リハビリテーションセンター/テ 731-3168 広島県広島市安佐南区伴南 1-39-1

Department of Rehabilitation Medicine, Hiroshima City General Rehabilitation Center

E-mail : hideyuna@yahoo.co.jp

Jpn J Rehabil Med unk. 50 mn. 52013 
Key words : 電子カルテ (electronic medical recoding system), 実態調査 (survey), 機能評価 (evaluation of function)，回復期リハビリテーション病棟（kaifukuki rehabilitation wards)

\section{はじめに}

回復期リハビリテーション病棟（以下，回リハ病 棟）における電子カルテ導入率は年々増加傾向にあ り，2011 年時点で $32.3 \%$ 上っている ${ }^{1)}$. 急性期病院 での電子カルテ化はさらに進んでおり, リハ医療に従 事するものは否応なく電子化への対応を余儀なくされ るものと考えられる.

リハ医療に求められるデータベースの要件は, (1)多 階層にわたる患者情報の入力，(2)情報の専門性と共有 性の両立, (3)データの定期的・継続的な入力・保存, (4)効率的なデータの保存と検索機能, (5)データの多目 的利用とされる2). 回リ八病棟で使用される電子カル テにはこれら要件が十分に盛り込まれ，多職種からな るリハチームの情報共有を促進し，作業効率の向上に 寄与することが期待されるが，実態は明らかでない.

当 WG はリハ医療が必要とする機能が電子カルテ にどの程度備わっているのか定量的に評価できる「電 子カルテ機能評価：回リ八病棟版」（以下，電カル機 能評価）を作成した ${ }^{3)}$ 。これは，診療録・評価・業務・ 文書等から回リ八病棟での情報共有や業務の効率化を 進めるうえで重要と考えられる 20 項目を抽出し, 各 項目に対して 1 ～点の 5 段階の評価尺度を定めたも のである. 5 段階の評価尺度は，回リハ病棟にとって 理想的な機能が備わっている状態を 5 点，必要最低限 の機能は満たすと考えられる状態を 3 点，機能不備が 甚だしい状態を 1 点とすることを共通原則として，詳 細な判定基準を項目ごとに定めた.

今回，この電カル機能評価を使用して，回リハ病棟 における電子カルテの実態調査を行ったので報告す る.

\section{調 查方法}

\section{1. 調査対象・方法}

2011 年 2 月時点で電子カルテを導入済みの回リハ 病棟を有する 153 施設（施設情報は回復期リハビリ テーション病棟協会から提供された）に対し，2011 年 10 月に郵送アンケート形式で実施した。アンケー トの回答は各施設の回リハ病棟の診療・電子カルテの
運営に携わる職員が記入した。回答者職種の内訳は, 事務職員 $40 \%$, 理学療法士 $27 \%$, 医師 $19 \%$, 作業 療法士 $6 \%$, 看護師 $4 \%$, 言語聴覚士 $2 \%$, 放射線技 師 $2 \%$ たた。

\section{2. 調查内容}

電子カルテ機能評価（回リハ病棟版）の自己採点結 果，電子カルテの使用期間・満足度を尋ねた。

\section{3. 回収率}

アンケートの回収率と有効回答率は，それぞれ $54.9 \% ， 53.6 \%$ (82 施設) だった。

\section{調 査 結 果}

\section{1. 使用期間}

電子カルテ使用期間は, 1 年未満 $1 \%, 1 \sim 3$ 年 $18 \%$, $3 \sim 5$ 年 $27 \%, 5 \sim 7$ 年 $32 \%, 7$ 年以上が $22 \%$ であ, 平均使用期間は 4.8 年だった。

\section{2. 満足度}

電子カルテへの満足度は, 大変満足 $0 \%$, ほぼ満足 $29 \%$, 普通 $49 \%$, やや不満 $17 \%$, 大変不満 $5 \%$ だっ た。

\section{3. 電カル機能評価の項目別結果（表）}

1）診療録に記載可能な職種と相互閲覧（中央值 5) $79 \%$ 施設が 5 点に該当し，これに 4 点を加える と $97 \%$ に達した。

\section{2）検索機能（中央值 4)}

3 点以上に該当する施設は $89 \%$ を占めたが，5点の 施設については $39 \%$ 留まり，検索機能が充足して いないことが示唆された。

3）担当者名の入力・表示（中央值 4)

5 点の施設は $30 \%$ に留まった。担当者名の情報が 十分に活用されていないことが示唆された。

\section{4）カンファレンス記録（中央值 3)}

5 点の施設はわずか $12 \%$ あ゙あ， 2 点以下の施設が $39 \%$ みられた。カンファレンスの定期的実施は必 須であるにもかかわらず，標準装備すらされていない システムが多く存在していた.

5）評価：日常生活動作（ADL）（中央值 3）

5 点の施設は $16 \%$ であり，これに 4 点の施設を加 えても $43 \%$ に留まった。一方で，2点以下の施設が 
23\%もあった．ADL 評価の情報共有は極めて重要で あるにもかかわらず，多くの電子カルテが十分に対応 できていないことが示唆された.

6）評価：身体機能（中央値 3)

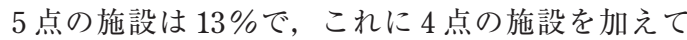
も $24 \%$ に留まった。一方で，2 点以下の施設が $49 \%$ と約半数もあった。

7) 評価：失語（中央值 2)

5 点の施設はわずか $8 \%$ あっあた． 2 点以下の施設 が $51 \%$ と過半数に上った。

8）評価：高次脳機能（中央值 2)

5 点の施設は $6 \%$ に留まり， 2 点以下の施設は $61 \%$ と過半数に上った.

\section{9）活動度の指示・確認（中央值 3）}

5 点の施設は $14 \%$ に留まったものの， 3 点以上の施 設は 7 割を超え，最低限の機能は概ね備わっているこ とが伺われた。

10）活動度の情報共有（中央值 3）

5 点の施設は $7 \%$ ，これに 4 点の施設を加えても 29\%に留まった．活動度の情報共有を容易にするた めの機能が十分でないことが示唆された.

11）給食（中央值 3)

3 点以上の施設が $93 \%$ を占めたが，5点の施設は 11\%に留まった。給食のオーダリング機能に関する 最低限の機能は備わっているが，食事内容に関する情 報共有の機能が不十分であることが示唆された.

12）患者スケジュール（中央值 3）

5 点の施設は $21 \%$ に留まり, 1 点の施設が $27 \%$ に も上った。

13）リハ総合実施計画書（中央值 3)

5 点の施設は $10 \%$ に留まり，2点以下の施設が $46 \%$ と半数近くにも上った。多くの電子カルテはリ 八総合実施計画書作成の作業効率向上に寄与していな いだけでなく，約半数は標準装備すらされていなかっ た。

14）リハ処方箋（中央值 4)

3 点以上が $90 \%$ 以上であったが， 5 点の施設はわず か $2 \%$ に留まった。リ八処方を出す作業は可能だが, リ八処方箋を介した効率的な情報活用についてもう一 歩踏み込んだ工夫が求められる結果となった。

15）補装具処方箋（中央值 1)

5 点の施設は $13 \%$ に留まり, 補装具処方䇝が電子 化されていない施設が $52 \%$ みられた。
16）クリニカルパス（中央値 2)

5 点の施設はわずか $14 \%$ 語り，クリニカルパス が電子化されていない施設が $49 \%$ にった.

17）電子カルテメーカー側のシステム改善への姿勢 (中央值 3)

5 点の施設はわずか $10 \%$ であたが， 3 点以上に該 当する施設については $79 \%$ に達した。

18）臨床データのエクスポート（中央值 2）

3 点（施設基準申請に必要な臨床デー夕を抽出でき る）以上に該当する施設はわずか $26 \% に$ 留まり，臨 床デー夕の二次利用が不十分であることが伺われた。 一方，4\%の施設は 5 点（リ八患者データベースの必 須項目をすべてエクスポートできる）の機能を備えて いた。

19）作業効率・反応速度（中央值 4)

病棟マップや患者一覧が開かれている状態から患者 カルテが展開されるまでの時間は，3秒未満：36\%, 3 秒以上 5 秒未満: $32 \% ， 5$ 秒以上 10 秒未満: $26 \%$, 15 秒以上：6\%であった．患者カルテを展開するだけ のために 5 秒以上もかかるシステムには反応速度の改 善を求めたい。

20）静止画・動画の保存・再生表示（中央値 2）

3 点以上の施設は $34 \%$ あ, さらには 5 点の施設 が 6\%もあった。予想以上に動画ファイルのネット ワーク化が進んでいることが伺われた。

4. 電カル機能評価と電子カルテへの満足度との相 関性（図）

電カル機能評価の総合計点と満足度との相関性につ いては, 統計学的にはスピアマンの順位相関 0.47 と 弱い相関を認めた。また満足度の点数を群とした多重 比較では, 満足度 4 点群が 1 点・ 2 点群に比べ優位に 機能評価の総点が高くなることから，今回 WG で作 成した電カル機能評価は, 回復期リ八病棟の現場が電 子カルテに求めているものをある程度反映できている と判断された。

\section{考察}

当 WG が作成した電カル機能評価をもとに，全国 の回リハ病棟を対象に電子カルテの実態調查を実施し た。

電カル機能評価 20 項目についての 5 段階の評価尺 度を決める際に，「理想的な機能が備わっている状態」 を 5 点とし，「該当情報を入力できるだけでなく， 
菅原英和 · 他

表＼cjkstart電カル機能評価の項目別結果 (1)

\begin{tabular}{|c|c|c|c|c|}
\hline $\begin{array}{l}\text { 大 } \\
\text { 項 } \\
\text { 目 }\end{array}$ & 小項目 & $\begin{array}{l}\text { 評価 } \\
\text { 尺度 }\end{array}$ & 評価尺度詳細 & 結果 \\
\hline \multirow{5}{*}{$\begin{array}{l}\text { 診 } \\
\text { 療 } \\
\text { 録 }\end{array}$} & \multirow{5}{*}{$\begin{array}{c}(1) \\
\text { 診療録に } \\
\text { 記載可能な } \\
\text { 職種と相互 } \\
\text { 閲覧 }\end{array}$} & 5 & 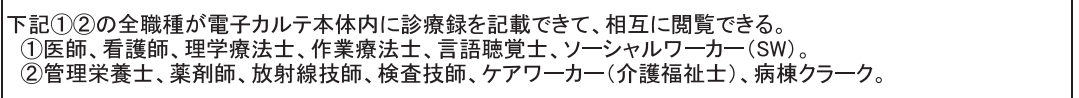 & $79 \%$ \\
\hline & & 4 & 1)の全職種および(2)の一部職種が電子カルテ本体内に診療録を記載できて、相互に閲覧できる。 & $18 \%$ \\
\hline & & 3 & $\begin{array}{l}\text { (1)の全職種が電子カルテ本体内に診療録を記載できて、相互に閲覧できる。 } \\
\text { (2)の職種はそれできな。 }\end{array}$ & $0 \%$ \\
\hline & & 2 & $\begin{array}{l}\text { (1)のうち一部職種が電子カルテ本体内には診療録を記載できないが、サブシステム等別個のシステムには記載で } \\
\text { き、相互の閲覧が可能である。 }\end{array}$ & $2 \%$ \\
\hline & & 1 & $\begin{array}{l}\text { 上記(1)のうち一部職種が電子カルテ本体内に診療録を記載できず、相互に閲覧できない。(サブシステムに記載で } \\
\text { きても(1)の職種間で相互に閲覧できなければ1点に相当する)。 }\end{array}$ & $0 \%$ \\
\hline
\end{tabular}

\begin{tabular}{|c|c|c|c|c|}
\hline \multirow{5}{*}{$\begin{array}{l}\text { 診 } \\
\text { 療 } \\
\text { 録 }\end{array}$} & \multirow{5}{*}{$\begin{array}{c}(2) \\
\text { 検索機能 }\end{array}$} & 5 & 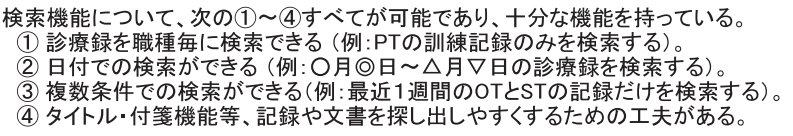 & $39 \%$ \\
\hline & & 4 & (1) (4)のうち1つの項目が不可能あるいは不十分である。 & $27 \%$ \\
\hline & & 3 & (1)〜 (4)のうち2つの項目が不可能あるいは不十分である。 & $23 \%$ \\
\hline & & 2 & (1) (4)のうち3つの項目が不可能あるいは不十分である。 & $7 \%$ \\
\hline & & 1 & (1)〜 (4)のすべてが不可能あるいは不十分である。 & $4 \%$ \\
\hline
\end{tabular}

\begin{tabular}{|c|c|c|c|c|}
\hline \multirow{5}{*}{$\begin{array}{l}\text { 診 } \\
\text { 療 } \\
\text { 録 }\end{array}$} & \multirow{5}{*}{$\begin{array}{c}\text { (3) } \\
\text { 担当者名 } \\
\text { の入力·表 } \\
\text { 示 }\end{array}$} & 5 & 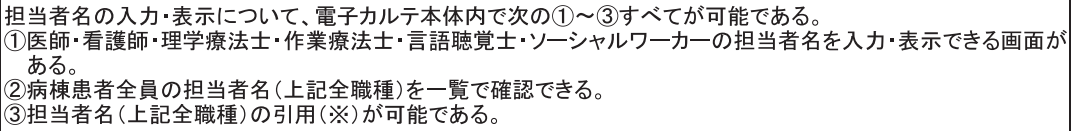 & $30 \%$ \\
\hline & & 4 & (1)は可能。(2)(3)のどちらかが不可能。 & $25 \%$ \\
\hline & & 3 & $\begin{array}{l}\text { (1)のみが可能、(2)(3)両方とも不可能(担当者名を入カ·表示できる画面はないが、実施計画書等他の入力欄を } \\
\text { 使って代用しているケースは2点とする)。 }\end{array}$ & $20 \%$ \\
\hline & & 2 & 担当者名の入力·表示が医師、看護師等一部職種に限定される。 & $22 \%$ \\
\hline & & 1 & 担当者名の入力·表示機能がない。 & $4 \%$ \\
\hline
\end{tabular}

※「担当者名の引用」とは、担当者名を一度入カすればカンファレンス画面や実施計画書やサマリー等他の画面にも自動的 に反映される機能のことを指す。

\begin{tabular}{|c|c|c|c|c|}
\hline \multirow{5}{*}{$\begin{array}{l}\text { 診 } \\
\text { 療 } \\
\text { 録 }\end{array}$} & \multirow{5}{*}{$\begin{array}{l}\text { (4) } \\
\text { カンファレ } \\
\text { ンス記録 }\end{array}$} & 5 & 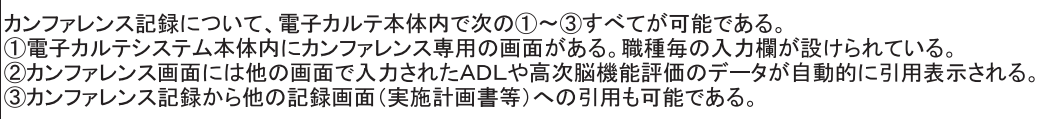 & $12 \%$ \\
\hline & & 4 & (1)は可能。(2)(3)のどちらかが不可能。 & $15 \%$ \\
\hline & & 3 & $\begin{array}{l}\text { (1)のみが可能。(2)(31両方とも不可能。 } \\
\text { (※エクセル・ワードフアイルでの作成·転送やサブシステムからの転送であっても、電子カルテ本体内で入力·編 } \\
\text { 集·保存ができ、情報が共有できれば3点とする)。 }\end{array}$ & $34 \%$ \\
\hline & & 2 & $\begin{array}{l}\text { (1)は不可能だが、サブシステムではカンファレンス記録の入カ·表示が可能(電子カルテ本体内には引用·転送さ } \\
\text { れない)。 }\end{array}$ & $26 \%$ \\
\hline & & 1 & $\begin{array}{l}\text { (1)は不可能で、サブシステムでもカンファレンス記録の入カ·表示ができない。 } \\
\text { 紙に記載して運用したり、紙のカンファレンス用紙をスキャンして運用している。 }\end{array}$ & $13 \%$ \\
\hline
\end{tabular}


表＼cjkstart電カル機能評価の項目別結果

(2)

\begin{tabular}{|c|c|c|c|c|}
\hline $\begin{array}{l}\text { 大 } \\
\text { 項 } \\
\text { 目 }\end{array}$ & 小項目 & $\begin{array}{l}\text { 評価 } \\
\text { 尺度 }\end{array}$ & 評価尺度詳細 & 結果 \\
\hline \multirow{5}{*}{$\begin{array}{l}\text { 患 } \\
\text { 者 } \\
\text { 評 }\end{array}$} & \multirow{5}{*}{$\begin{array}{l}(5) \\
A D L\end{array}$} & 5 & 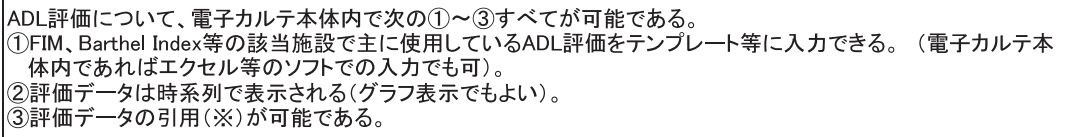 & $16 \%$ \\
\hline & & 4 & (1)(2)は可能だが、(3)が不可能。 & $27 \%$ \\
\hline & & 3 & (1)のみが可能。(2)·(3)は両方とも不可能。 & $34 \%$ \\
\hline & & 2 & (1)は不可能だが、サブシステムではADL評価を入カ·表示することができる。 & $16 \%$ \\
\hline & & 1 & $\begin{array}{l}\text { (1)が不可能。サブシステムでもADL評価の入カ·表示ができない。 } \\
\text { (2号用紙等にテキストで手入カして場合や紙の評価用紙をスキャナー保存している場合も1点に該当する)。 }\end{array}$ & $7 \%$ \\
\hline & & & $\begin{array}{l}\text { ※「評価データの引用」とは、デンプレートに入カした数值がカンファレンス画面や実施計画書やサマリ一等他の画 } \\
\text { に反映される機能のことを指す。 }\end{array}$ & 自動的 \\
\hline \multirow{5}{*}{$\begin{array}{l}\text { 患 } \\
\text { 者 } \\
\text { 評 } \\
\text { 価 }\end{array}$} & \multirow{5}{*}{$\begin{array}{c}\text { (6) } \\
\text { 身体機能 }\end{array}$} & 5 & 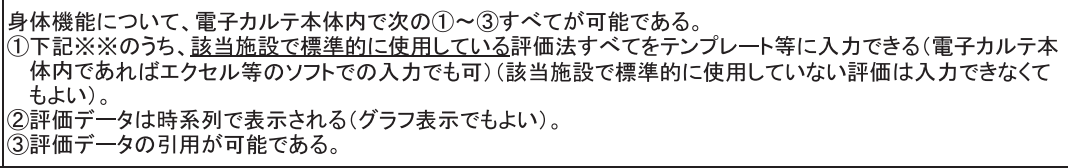 & $13 \%$ \\
\hline & & 4 & (1)(2)は可能だが、(3)が不可能。 & $11 \%$ \\
\hline & & 3 & (1)のみが可能。(2)-(3)は両方とも不可能。 & $27 \%$ \\
\hline & & 2 & $\begin{array}{l}\text { 下記※※のうち該当施設で使用している評価の二部しかテンプレート等に入カできない (サブシステムで入カ·表 } \\
\text { 示ができる場合は2点とする)。 }\end{array}$ & $20 \%$ \\
\hline & & 1 & $\begin{array}{l}\text { 下記※※のうち該当施設で使用している評価全てが、テンプレート等やサブシステムに入カ•表示できない。(2号 } \\
\text { 用紙等にテキストで手入カしてい場合や紙評価用紙をスキャナー保存している場合も1点に該当する)。 }\end{array}$ & $29 \%$ \\
\hline & & & $\begin{array}{l}\text { ※※Brunnstrom Stage、上田式12グレード片麻㾇機能テスト、SIAS、STEF、Berg Balance Scale、Functional Reach } \\
\text { ROM、MMT、Modified Ashworth Scale（該当施設で標準的に使用していない評価は入カできなくてもよい)。 }\end{array}$ & \\
\hline \multirow{5}{*}{$\begin{array}{l}\text { 患 } \\
\text { 者 } \\
\text { 評 }\end{array}$} & \multirow{5}{*}{$\begin{array}{l}(7) \\
\text { 失語 }\end{array}$} & 5 & 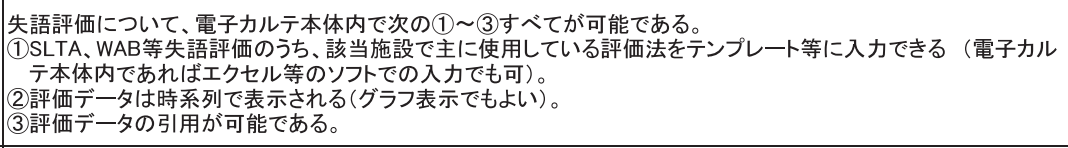 & $8 \%$ \\
\hline & & 4 & (1)(2)は可能だが、(3)が不可能。 & $24 \%$ \\
\hline & & 3 & (1)のみが可能。(2)-(3)は両方とも不可能。 & $18 \%$ \\
\hline & & 2 & (1)は不可能だが、サブシステムでは失語評価を入カ·表示することができる。 & $10 \%$ \\
\hline & & 1 & $\begin{array}{l}\text { (1)゙不可能。サブシステムでも失語評価を入カ·表示することができない。 } \\
\text { (2号用紙等にテテキストで手入カしている場合や紙の評価用紙をスキャナー保存している場合も1点に該当する)。 }\end{array}$ & $41 \%$ \\
\hline
\end{tabular}

\begin{tabular}{|c|c|c|c|c|}
\hline \multirow{5}{*}{$\begin{array}{l}\text { 患 } \\
\text { 者 } \\
\text { 価 }\end{array}$} & \multirow{5}{*}{$\begin{array}{c}(8) \\
\text { 高次脳機 } \\
\text { 能 }\end{array}$} & 5 & 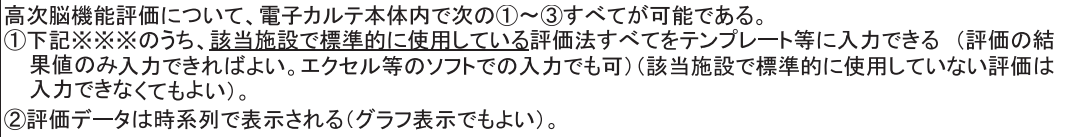 & $6 \%$ \\
\hline & & 4 & (1)(2)は両方とも可能だが、(3)が不可能。 & $11 \%$ \\
\hline & & 3 & (1)のみが可能。(2)-(3)は両方とも不可能。 & $23 \%$ \\
\hline & & 2 & $\begin{array}{l}\text { 下記※※※※のうち該当施設で使用している評価の一部しかテンプレート等に入カできない (サブシステムに入カ・ } \\
\text { 表示ができる場合は2点とする)。 }\end{array}$ & $28 \%$ \\
\hline & & 1 & 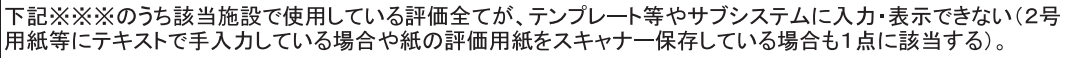 & $33 \%$ \\
\hline
\end{tabular}

銘力検査、ベントン視覚記銘力検査、BIT(該当施設で標準的に使用していない評価は入力できなくてもよい)。 
菅原英 和 - 他

表 電カル機能評価の項目別結果 (3)

\begin{tabular}{|c|c|c|c|c|}
\hline $\begin{array}{l}\text { 不 } \\
\text { 項 }\end{array}$ & 小項目 & $\begin{array}{l}\text { 評価 } \\
\text { 尺度 }\end{array}$ & 評価尺度詳細 & 結果 \\
\hline \multirow{5}{*}{ 業 } & \multirow{5}{*}{$\begin{array}{c}(9) \\
\text { 活動度の } \\
\text { 指示·確認 }\end{array}$} & 5 & 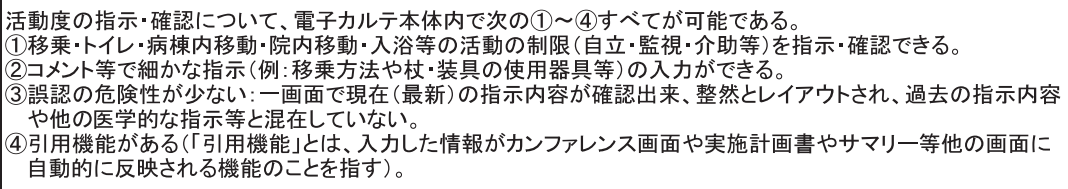 & $14 \%$ \\
\hline & & 4 & (1)は可能。(2)(3)(4)のうち1つが不可能。 & $27 \%$ \\
\hline & & 3 & (1)は可能。(2)(3)(4)のうち2つが不可能。 & $36 \%$ \\
\hline & & 2 & (1)のみが可能。(2)(3)(4)は全て不可能。 & $6 \%$ \\
\hline & & 1 & $\begin{array}{l}\text { (1)が不可能(2号用紙等にテキストで手入カしている場合や紙の評価用紙をスキャナ一保存している場合も1点に } \\
\text { 該当する)。 }\end{array}$ & $17 \%$ \\
\hline
\end{tabular}

\begin{tabular}{|c|c|c|c|c|}
\hline \multirow{5}{*}{$\begin{array}{l}\text { 業 } \\
\text { 務 }\end{array}$} & \multirow{5}{*}{$\begin{array}{c}(10) \\
\text { 活動度の } \\
\text { 情報共有 }\end{array}$} & 5 & 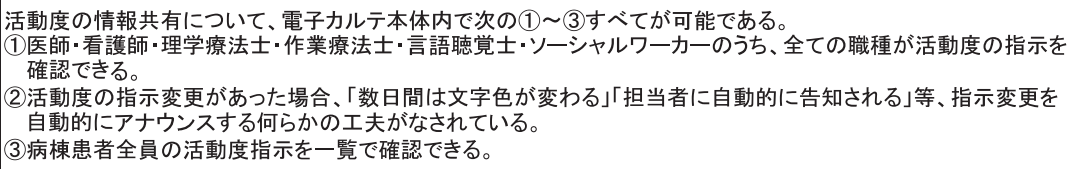 & $7 \%$ \\
\hline & & 4 & (1)は可能。(2)(3)のどちらかが不可能。 & $22 \%$ \\
\hline & & 3 & (1)のみが可能。(2)(3)は両方とも不可能。 & $49 \%$ \\
\hline & & 2 & 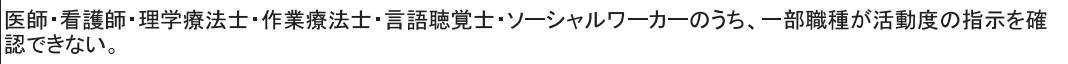 & $6 \%$ \\
\hline & & 1 & 活動の制限を指示·確認するための画面がない。 & $16 \%$ \\
\hline
\end{tabular}

\begin{tabular}{|c|c|c|c|c|}
\hline \multirow{5}{*}{$\begin{array}{l}\text { 業 } \\
\text { 務 }\end{array}$} & \multirow{5}{*}{$\begin{array}{l}\text { (11) } \\
\text { 給食 }\end{array}$} & 5 & 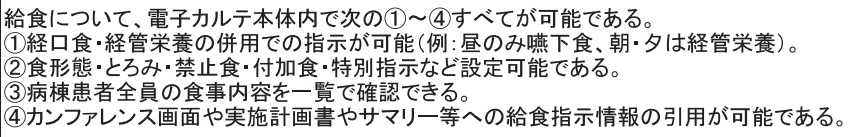 & $11 \%$ \\
\hline & & 4 & (1)(2)は両方とも可能。(3)(4)のどちらかが不可能。 & $36 \%$ \\
\hline & & 3 & (1)(2)は両方とも可能。(3)44は両方とも不可能。 & $46 \%$ \\
\hline & & 2 & (1)(2)のどちらかが可能。(3)(4)は両方とも不可能。 & $4 \%$ \\
\hline & & 1 & (1)(2)の両者とも不可能。 & $3 \%$ \\
\hline
\end{tabular}

\begin{tabular}{|c|c|c|c|c|}
\hline \multirow{5}{*}{ 業 } & \multirow{5}{*}{ 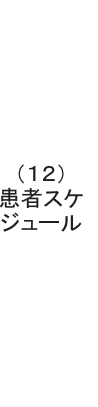 } & 5 & $\begin{array}{l}\text { 患者スケジュールについて、電子カルテ本体内で次の1) (4)すべてが可能である。 } \\
\text { (1)PT·OT·ST訓練の開始·終了時間を確認できる。 } \\
\text { (2)入浴·面談の予定確認できる。 } \\
\text { (3)他科受診·検榃·栄養指導·退院前訪問など(1)(2)以外で必要な予定を確認できる。 }\end{array}$ & $21 \%$ \\
\hline & & 4 & (1)が可能。(2)(3)(4)のうち1つが不可能。 & $21 \%$ \\
\hline & & 3 & (1)が可能。(2)(3)(4)のうち2つが不可能。 & $16 \%$ \\
\hline & & 2 & (1)が可能。(2)(3)(4)はすべて不可能。 & $16 \%$ \\
\hline & & 1 & (1)が不可能。 & $27 \%$ \\
\hline
\end{tabular}


表 電カル機能評価の項目別結果 (4)

\begin{tabular}{|c|c|c|c|c|}
\hline $\begin{array}{l}\text { 大 } \\
\text { 項 } \\
\text { 目 }\end{array}$ & 小項目 & $\begin{array}{l}\text { 評価 } \\
\text { 尺度 }\end{array}$ & 評価尺度詳細 & 結果 \\
\hline \multirow{5}{*}{$\begin{array}{l}\text { 文 } \\
\text { 書 }\end{array}$} & \multirow{5}{*}{$\begin{array}{l}\text { (13) } \\
\text { リ八総合実 } \\
\text { 施計画書 }\end{array}$} & 5 & $\begin{array}{l}\text { リハ総合実施計画書について、次の(1) (3)すべての条件を満たしている。 } \\
\text { (1)電子カルテ本体内にリ総合実施計画書が標準的に装備されている。 } \\
\text { (2)患者基本情報(※)は自動的に引用される。 } \\
\text { (3)患者基本情報以外の項目について、全体の半分以上の項目が自動的に引用される。 }\end{array}$ & $10 \%$ \\
\hline & & 4 & (1)は満たす。(2)(3)のうち1つを満たさない。 & $37 \%$ \\
\hline & & 3 & (1)は満たすが、(2)(3)両方とも満たさない。 & $9 \%$ \\
\hline & & 2 & $\begin{array}{l}\text { 電子カルテ本体内にリ八総合実施計画書が標準的に装備されていなかったが、特別注文によって装備してもらい } \\
\text { 使用している。またはサブシステムのリハ総合実施計画書を使用している。 }\end{array}$ & $37 \%$ \\
\hline & & 1 & $\begin{array}{l}\text { リハ総合実施計画書が電子化されていない。 } \\
\text { (紙のリハ処方箋をスキャナ一保存している場合も1点とする)。 }\end{array}$ & $9 \%$ \\
\hline
\end{tabular}

※患者基本情報: ID, 氏名, 年齢, 性別, 主病名, 障害名, 発症日, 入院日

\begin{tabular}{|c|c|c|c|c|}
\hline \multirow{5}{*}{$\begin{array}{l}\text { 文 } \\
\text { 書 }\end{array}$} & \multirow{5}{*}{$\begin{array}{l}(14) \\
\text { リハ処方箋 }\end{array}$} & 5 & 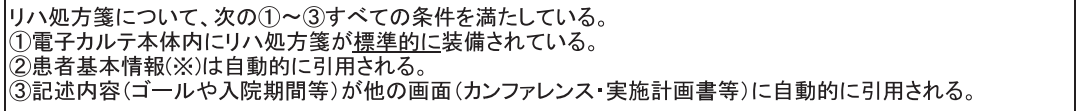 & $2 \%$ \\
\hline & & 4 & (1)は満たす。(2)(3)のうち1つを満たさない。 & $73 \%$ \\
\hline & & 3 & (1)は満たすが、(2)(3両方とも満たさない。 & $15 \%$ \\
\hline & & 2 & $\begin{array}{l}\text { 電子カルテ本体内にリハ処方踐が標準的に装備されていなかったが、特別注文によって装備してもらい使用してい } \\
\text { る。たはサブシスムのリハ処方箋を使用している。 }\end{array}$ & $9 \%$ \\
\hline & & 1 & $\begin{array}{l}\text { リハ処方嘎が電子化されていない(リハ処方を2号用紙等にテキストで手入力している場合や紙のリハ処方嘎をス } \\
\text { キャナー保存している場合も1点とする)。 }\end{array}$ & $1 \%$ \\
\hline
\end{tabular}

※患者基本情報:ID, 氏名, 年齢, 性別, 主病名, 障害名, 発症日, 入院日

\begin{tabular}{|c|c|c|c|c|}
\hline \multirow{5}{*}{$\begin{array}{l}\text { 文 } \\
\text { 書 }\end{array}$} & \multirow{5}{*}{$\begin{array}{l}\text { (15) } \\
\text { 補装具処 } \\
\text { 方箋(義 } \\
\text { 肢·装具) }\end{array}$} & 5 & $\begin{array}{l}\text { 補装具処方箋について、次の(1) (3)すべての条件を満たしている。 } \\
\text { (1)電子カル本体内に補装具処方箋が標準的に装備されている。 } \\
\text { (2)患者基本情報(※)は自動的に引用される。 } \\
\text { (3)過去の処方歴·処方内容を簡単に参照できる。 }\end{array}$ & $13 \%$ \\
\hline & & 4 & (1)は満たす。(2)(3)のうち1つを満たさない。 & $13 \%$ \\
\hline & & 3 & (1)は満たすが、(2)(3)は両方とも満たさない。 & $5 \%$ \\
\hline & & 2 & $\begin{array}{l}\text { 電子カルテ本体内に補装具処方簼が標準的に装備されていなかったが、特別注文によって装備してもらい使用し } \\
\text { ている。たはサブシステムの補装具処方箋を使用している。 }\end{array}$ & $16 \%$ \\
\hline & & 1 & $\begin{array}{l}\text { 補装具処方箋が電子化されていない(補装具処方を2号用紙等にテキストで手入力している場合や紙の補装具処 } \\
\text { 方箋をスキャナー保存している場合は1点とする)。 }\end{array}$ & $52 \%$ \\
\hline
\end{tabular}

\begin{tabular}{|c|c|c|c|c|}
\hline \multirow{5}{*}{$\begin{array}{l}\text { そ } \\
\text { の } \\
\text { 他 }\end{array}$} & \multirow{5}{*}{$\begin{array}{c}\text { (16) } \\
\text { クリニカル } \\
\text { パス }\end{array}$} & 5 & 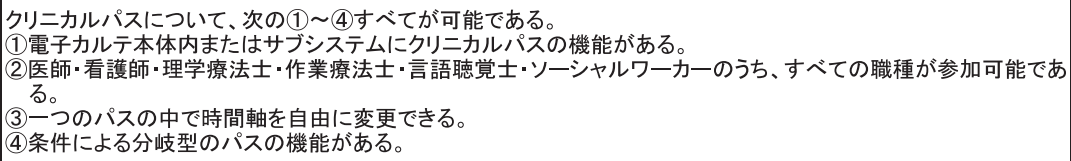 & $14 \%$ \\
\hline & & 4 & (1)(2)(3)が可能、(4)は不可能。 & $9 \%$ \\
\hline & & 3 & (1)(2)が可能、(3)は困難で日めくりにしか対応できない、(4)は不可能。 & $15 \%$ \\
\hline & & 2 & (1)が可能、(2)は困難で一部の職種が参加できない。 & $14 \%$ \\
\hline & & 1 & クリニカルパスの機能がない。 & $49 \%$ \\
\hline
\end{tabular}


菅原英和・他

表＼cjkstart電カル機能評価の項目別結果（5）

\begin{tabular}{|c|c|c|c|c|}
\hline $\begin{array}{l}\text { 大 } \\
\text { 項 } \\
\text { 目 }\end{array}$ & 小項目 & $\begin{array}{l}\text { 評価 } \\
\text { 尺度 }\end{array}$ & 評価尺度詳細 & 結果 \\
\hline \multirow{5}{*}{$\begin{array}{l}\text { そ } \\
\text { の } \\
\text { 他 }\end{array}$} & \multirow{5}{*}{$\begin{array}{l}\text { (17) } \\
\text { 電子カルテ } \\
\text { メーカ側 } \\
\text { のシステム } \\
\text { 改善への } \\
\text { 姿勢 }\end{array}$} & 5 & 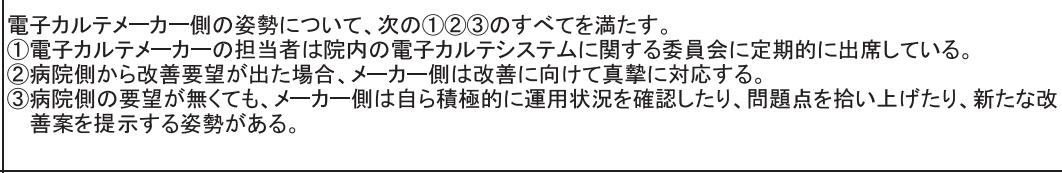 & $10 \%$ \\
\hline & & 4 & (1)(2)(3)うち、2つを満たす。 & $30 \%$ \\
\hline & & 3 & (1)(2)(3うち、1つを満たす。 & $39 \%$ \\
\hline & & 2 & (1)(2)(3)のいずれも満たさない。改善要望に答えてくれることはある。 & $17 \%$ \\
\hline & & 1 & (1)(2)(3)のいずれも満たさない。改善要望に答えてくれない。 & $4 \%$ \\
\hline
\end{tabular}

\begin{tabular}{|c|c|c|c|c|}
\hline \multirow{5}{*}{$\begin{array}{l}そ \\
\text { の } \\
\text { 他 }\end{array}$} & \multirow{5}{*}{$\begin{array}{l}\text { (18) } \\
\text { 臨床データ } \\
\text { のエクス } \\
\text { ポート }\end{array}$} & 5 & $\begin{array}{l}\text { リハビリテーション患者データベース※の「脳卒中転入院用※※」および「大腿骨頸部骨折用※※※」の必須項目 } \\
\text { をすべてエクスボート(！！)することができる。 }\end{array}$ & $4 \%$ \\
\hline & & 4 & 下記(1)より多くの項目をエクスポートすることができる。 & $10 \%$ \\
\hline & & 3 & $\begin{array}{l}\text { 次の1)の項目をすべてエクスポートできる。 } \\
\text { (1)患者基本情報 (ID, 氏名, 年齢, 性別, 主病名, 障害名, 発症日, 入院日, 退院日)および回復期リハ病棟の施 } \\
\text { 設基準申請に必要な臨床データ(入院時·退院時の日常生活機能評価, 退院先, リハ施行単位数)。 }\end{array}$ & $12 \%$ \\
\hline & & 2 & 上記11の項目のうち、一部をエクスポートすることができない。 & $37 \%$ \\
\hline & & 1 & 上記(1)の項目全てのエクスポートができない。 & $38 \%$ \\
\hline
\end{tabular}

※http://square.umin.ac.jp/jarm-db/index.html
※http://square.umin.ac.jp/jarm-db/download/checklist tennyuuin.pdf

※※.http://square.umin.ac.jp/jarm-db/download/checklist_daitaikotsu.pdf

! ! エクスポートとは電子カルテ内からデータを何らかのファイル形式(Excel等)にして取り出す機能のこと。指定された管理 者のみが実施できる

\begin{tabular}{|c|c|c|c|c|}
\hline \multirow{5}{*}{$\begin{array}{l}\text { そ } \\
\text { の } \\
\text { 他 }\end{array}$} & \multirow{5}{*}{$\begin{array}{c}\text { (19) } \\
\text { 作業効率- } \\
\text { 反応速度 }\end{array}$} & 5 & $\begin{array}{l}\text { <作業効率·反応速度の評価方法>病棟マップや患者一覧が開かれている状態から、患者カルテが展開されるま } \\
\text { での時間をストップウオツチで測定する。 } \\
\text {-病棟内のパソコンで3回測定し、最速値を結果とする。 } \\
\text {-作業効率が極端に下がる時間帯での測定は避ける。 } \\
\text { 結果: 秒未満 }\end{array}$ & $36 \%$ \\
\hline & & 4 & 結果: 3秒以上5秒未満 & $32 \%$ \\
\hline & & 3 & 結果: 5 秒以上 10 秒未満 & $26 \%$ \\
\hline & & 2 & 結果: 10秒以上 15 秒未満 & $0 \%$ \\
\hline & & 1 & 結果: 15秒以上 & $6 \%$ \\
\hline
\end{tabular}

\begin{tabular}{|c|c|c|c|c|}
\hline \multirow{5}{*}{$\begin{array}{l}\xi \\
\text { の } \\
\text { 他 }\end{array}$} & \multirow{5}{*}{$\begin{array}{c}\text { (20) } \\
\text { 静止画·動 } \\
\text { 画の保存· } \\
\text { 再生表示 }\end{array}$} & 5 & 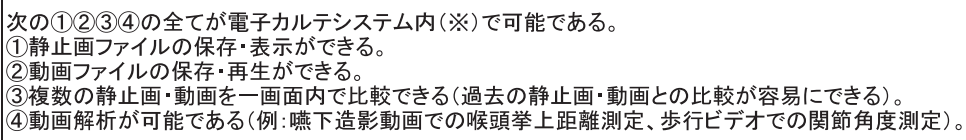 & $6 \%$ \\
\hline & & 4 & (1)(2)は両方とも可能。(3)(4)のどちらかが不可能。 & $17 \%$ \\
\hline & & 3 & (1)(2)は両方とも可能。(3)(4)は両方とも不可能。 & $11 \%$ \\
\hline & & 2 & (1)のみが可能。(2)(3)(4)はすへて不可能。 & $47 \%$ \\
\hline & & 1 & (1)(2)(3)す)べて不可能。 & $19 \%$ \\
\hline
\end{tabular}

※「電子カルテシステム内で可能」とは電子カルテ上で保存·表示·再生ができる状態を意味する。電子カルテ上で起動できれ ば、サブシステムとして別のソフトを起動してもよい。 


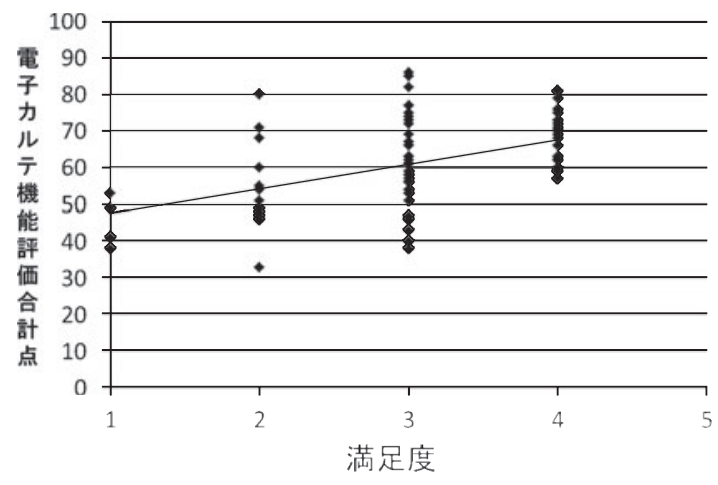

図 電子カルテ機能評価と電子カルテへの満足度と の相関性

チーム内での情報共有が促進され，業務負担を軽減で きるような工夫が施されている」ことを必要条件とし た.とりあえず入力・保存ができる程度を「最低限必 要な基準を満たす」状態の 3 点とし，まったく機能が 備わっていない等「機能不備が甚だしい状態」を 1 点 とした. 20 項目を中央值別に分類した結果，5点：1 項目, 4 点: 4 項目, 3 点: 9 項目, 2 点: 5 項目, 1 点: 1 項目となり, 全体として理想的な状態からはほど遠 い状態であった．特に中央值 2 以下だった項目のうち 高次脳機能・失語評価や装具処方箋などはリ八医療に 欠かせない項目であり，それらの情報をテンプレート に入力することすらできない施設が過半数あったとい う結果はとても許容できるものではない.リ八医療特 有のニーズに多くのシステムが対応しきれていないこ とがあらためて伺われた。

また, 各項目別での最小值・最大值は全項目で 1 点 から 5 点までの大きなばらつきがあり，施設によって 電子カルテのリハ関連機能に相当の差があることが判
明した.これらの差は主に, 電子カルテのシステム (メーカー）による差と，各施設がどの程度カスタム オーダーを追及したのかによる差であると考えられ る。施設間でこれほどまでに差が生じている状態は大 きな問題である．今後システム間あるいは施設間の差 が縮まるような取り組みが求められる

電カル機能評価の評価項目・尺度が限られたメン バーにより作成されたこと, 実際の調査が各病院ス タッフによる自己評価であったことより，評価項目・ 尺度の妥当性や得られた結果の信頼性については慎重 に検討する必要があるが，回リハ病棟を取り巻く電子 カルテの現状や問題点をおおまかに捉えることがで き, 今後のリハ医療に必要な電子カルテ像について検 討できたことは大きな成果であると考えている.

当 WGの活動を支援していただいた日本リハビリテー ション医学会専門医会幹事の先生方，面倒な調査にもかか わらずご協力いただいた回復期リハビリテーション病棟の 皆様, 電子カルテ導入施設情報を提供していただいた回復 期リハビリテーション病棟協会の関係者に心より感謝申し 上げます．このWGの活動が電子カルテおよびリハ医療の 質の向上につながっていくことを心から願っております.

\section{文献}

1）全国回復期リハビリテーション病棟連絡協議会 : 回復 期リハビリテーション病棟の現状と課題に関する調査 報告書平成 23 年度版. 2012

2) 才藤栄一, 園田 茂 編 : FITプログラム. 医学書院, 東 京, 2003

3）菅原英和, 越智光宏, 岡崎英人, 嘉村雄飛, 原田雄大, 八 幡徹太郎: リハ医療に必要な電子カルテ機能を検討す るワーキンググループWG活動報告. Jpn J Rehabil Med $2012 ; 49$ : 342-348 